\title{
BIOLOGI Sitophilus oryzae dan Sitophilus zeamais (COLEOPTERA; CURCULIONIDAE) PADA BERAS DAN JAGUNG PIPILAN
}

\author{
BIOLOGY OF Sitophilus oryzae AND Sitophilus zeamais (COLEOPTERA; \\ CURCULIONIDAE) ON RICE AND CORN SEED
}

\author{
Jusuf Manueke, Max Tulung dan J.M.E. Mamahit*) \\ *)Jurusan Hama dan Penyakit Tumbuhan, Fakultas Pertanian Unsrat Manado 95115
}

\begin{abstract}
This study aims to determine the biological of Sitophilus oryzae and S. zeamais which includes development stadia, life cycle, long life, fecundity, mortality and sex ratio. Research using descriptive and substitutional methods. The research conducted in the laboratory of Entomology and Plant Pests and Pest Department of Pest and Disease Faculty of Agriculture Sam Ratul;angi University Manado. The results showed differences in the life cycle, long life and fecundity between $S$. oryzae and $S$. zeamais. Long life cycle and life imago $S$. oryzae shorter than $S$. zeamais. The life cycle of $S$. oryzae is 35.22 days and $S$. zeamais 49.13 days. Life long female imago $S$. oryzae 101 days and 88.75 days males, S. zeamais females and males 109.25125 .75 day day. Fecundity of $S$. oryzae lower than S. zeamais namely $S$. oryzae average 152.8 points and $S$. zeamais average of 203.0 points. Pradewasa mortality and sex ratio of $S$. oryzae and $S$. zeamais unchanged at $S$. oryzae $80.5 \%$ and $0.79, S$. zeamais $77.0 \%$ and 0.77 .
\end{abstract}

Keywords: Sitophilus oryzae, Sitophilus zeamais, development stadia, life cycle, long life, fecundity, mortality

\begin{abstract}
ABSTRAK
Penelitian ini bertujuan untuk mengetahui biologi $S$. oryzae dan S. zeamais yang meliputi stadia perkembangan, siklus hidup, lama hidup, fekunditas, mortalitas dan rasio kelamin. Penelitian menggunakan metode deskriptif dan substitusi. Hasil penelitian menunjukkan perbedaan siklus hidup, lama hidup dan fekunditas antara S. oryzae dan S. zeamais. Siklus hidup dan lama hidup imago $S$. oryzae lebih pendek dari $S$. zeamais. Siklus hidup $S$. oryzae yaitu 35,22 hari dan $S$. zeamais 49,13 hari. Lama Hidup imago betina S. oryzae 101 hari dan jantan 88,75 hari, S. zeamais betina 125,75 hari dan jantan 109,25 hari. Fekunditas S. oryzae lebih rendah dari S. zeamais yaitu S. oryzae rata-rata 152,8 butir dan $S$. zeamais rata-rata 203,0 butir. Mortalitas pradewasa dan rasio kelamin S. oryzae dan S. zeamais relatif sama yaitu $S$. oryzae $80,5 \%$ dan 0,79 , S. zeamais $77,0 \%$ dan 0,77 .

Kata kunci : Sitophilus oryzae, Sitophilus zeamais, stadia perkembangan, siklus hidup, lama hidup, fekunditas, mortalitas
\end{abstract}




\section{PENDAHULUAN}

Serangga ini pertama kali dideskripsikan oleh Linnaeus pada tahun 1798 sebagai Curculio oryzae yang kemudian direvisi oleh De Clairville dan Scheltenburg, sehingga berubah nama menjadi Calandra oryzae. Para peneliti sesudah masa itu menemukan dua perbedaan ukuran pada serangga tersebut yaitu ada yang besar dan ada yang kecil. Tahun 1855, Motschulsky menyatakan bahwa serangga yang berukuran besar memang berbeda dengan yang kecil dan dia memberikan nama Sitophilus zeamais untuk serangga yang ukurannya lebih besar. Sayangnya hanya sebagian kecil peneliti yang mengetahui tentang revisi yang dilakukan oleh Motschulsky sehingga nama Calandra masih terus digunakan untuk komplek serangga jenis ini. Pada tahun 1928 dan 1931 Takahashi menyatakan bahwa serangga yang berukuran kecil secara khusus dinamai Calandra sasakii (Floyd dan Newsom, 1959; Kalshoven, 1981; Suputa, 2003).

Serangga ini merupakan hama utama pada komoditas pascapanen biji-bijian terutama yang merupakan bahan pangan penting bagi kehidupan manusia seperti gabah/beras, jagung pipilan, gandum, gaplek dan lain-lain. Menurut Brands (2006) dalam Anonim (2010) bahwa klasifikasi serangga ini sebagai berikut :

$\begin{array}{ll}\text { Domain } & \text { : Eukaryota (Whittaker dan } \\ & \text { Margulis, 1978) } \\ \text { Kingdom } & \text { : Animalia (Linnaeus, 1978) } \\ \text { Subkingdom } & \text { : Bilateria (Hatschek, 1888) } \\ \text { Branch } & \text { : Protostomia (Grobben, 1908) } \\ \text { Infrakingdom } & \text { : Ecdyozoa (Aguinaldo Et. Al., } \\ & \text { 1997 Ex Cavalier-Smith, 1998) } \\ \text { Superphylum } & \text { : Panarthropoda (Cuviier) } \\ \text { Phylum } & \text { : Arthropoda (Latreille, 1829) } \\ \text { Subphylum } & \text { : Mandibulata (Snograss, 1938) } \\ \text { Infraphylum } & \text { : Atelocerata (Heymons, 1901) } \\ \text { Superclass } & : \text { Panhexapoda } \\ \text { Epiclass } & : \text { Hexapoda } \\ \text { Class } & : \text { Insecta (Linnaeus, 1758) } \\ \text { Subclass } & : \text { Dycondylia } \\ \text { Infraclass } & : \text { Pterygota } \\ \text { Order } & : \text { Coleoptera (C. Linneaus, 1758) } \\ \text { Suborder } & : \text { Polyphaga (Emery, 1886) }\end{array}$

$\begin{array}{ll}\text { Infraorder } & \text { : Cucujiformia } \\ \text { Superfamily } & \text { : Curculionoidea } \\ \text { Family } & \text { : Curculionidae } \\ \text { Genus } & \text { : Sitophilus (Linnaeus, 1758) } \\ \text { Species } & : \text { Sitophilus oryzae, S. zeamais, } \\ & \text { S. granaries, S. linearis. }\end{array}$

Imago Sitophilus spp. berwarna hitam, hitam kecoklatan dan coklat. Serangga betina bertelur sepanjang stadium dewasa. Setiap betina mampu bertelur lebih dari 150 butir. Telur diletakkan satu per satu dalam lubang yang dibuat oleh serangga betina pada biji yang diserangnya. Telur dilindungi oleh lapisan lilin/gelatine hasil sekresi serangga betina. Periode telur berlangsung selama 6 hari pada suhu $25^{\circ} \mathrm{C}$. Setelah menetas, larva segera memakan bagian biji yang di sekitarnya dan membentuk lubang-lubang gerekan. Larva terdiri dari empat instar. Periode pupa berlangsung di dalam biji. Serangga dewasa yang baru muncul segera membuat jalan keluar dengan cara menggerek bagian biji tersebut sehingga membentuk lubang besar yang karakteristik. Total periode perkembangan serangga ini antara 35 - 40 hari, tergantung jenis dan mutu biji yang diserangnya (Kalshoven, 1981; Anonim, 2009).

Beberapa karakteristik dari hama ini adalah sebagai berikut : a) Imago ketika masih umur muda berwarna hitam kecoklatan dan coklat kemerahan, setelah tua warnanya berubah menjadi hitam dan coklat. Pada kedua buah sayap bagian depan masing-masing terdapat dua buah bercak berwarna kuning agak kemerahan (S. oryzaea dan S. zeamais). S. linearis dan S. granaries tidak memiliki spot pada elytra; b) Panjang tubuh imago antara 3,5 $-5 \mathrm{~mm}$, tergantung spesies dan tempat hidupnya, artinya pada material yang lebih besar (misalnya butiran jagung atau potongan gaplek) ukuran tubuhnya lebih besar yaitu sekitar $4,5 \mathrm{~mm}$, lebih besar daripada larva yang hidup pada butiran beras; c) Larvanya tidak berkaki, berwarna putih jernih. Ketika melakukan gerakan tubuhnya selalu membentuk seperti agak bulat, mengkerut, sedangkan kepompongnya tampak seakan-akan telah dewasa (Anonim, 1882; Cotton, 1980;

Aktivitas perkembangbiakan, makan, dan kopulasi umumnya dilakukan pada malam hari. Imago betina meletakkan telurnya pada tiap butiran 
bebijian yang telah dilubanginya terlebih dahulu. Setiap lubang gerekan diletakkan satu butir telur, selanjutnya lubang gerekan tersebut ditutup dengan tepung sisa-sisa gerekan yang di rekat dengan zat gelatine yang sekresikan oleh imago betina. Stadium telur sekitar tujuh hari. Larva yang keluar dari telur langsung menggerek bebijian (butiran Beras, Jagung dan lain-lain) dan stadium larva berada dalam biji dan melanjutkan serangannya di dalam biji tersebut. Larva tidak berkaki, stadium larva berlangsung 7 - 10 hari. Pupa berada dalam biji sampai menjadi imago. Stadium pupa berlangsung 7-12 hari. Imago setelah keluar dari pupa akan tetap berada di dalam lubang/biji sekitar lima hari. Siklus hidup hama ini berlangsung sekitar 31 hari (Sartikanti, 2004; Tjoa Tjien Mo, 1953).

Dikenal beberapa spesies penting dalam genus Sitopihilus yaitu $S$. oryzae, $S$. zeamais, $S$. linearis dan $S$. granarius. S. oryzae dikenal dengan nama bubuk beras atau rice weevil, karena merupakan hama utama pada beras dan gabah. $S$. zeamais dikenal dengan nama bubuk jagung atau maize weevil karena merupakan hama utama pada jagung pipilan/biji jagung. S. granaries dikenal dengan nama bubuk gandum atau wheat weevil karena menyerang simpanan gandum. S. linearis dikenal dengan nama bubuk biji asem atau tamarind weevil karena merupakan hama pada biji Asam Jawa. Imago Sitophilus spp. dapat dilihat pada Gambar 1 (Anonim, 2010).

Dulunya $S$. oryzae dikenal dengan nama lain yaitu Calandra oryzae L., kemudian Schoenher (1838), mendeskripsikannya kembali dengan nama Sitophilus oryzae. Di Indonesia dikenal dengan nama bubuk beras atau kumbang beras, di Sulawesi Utara disebut logong dan di Minahasa disebut lowong atau kutu beras, sedangkan di luar negeri disebut rice weevil. Beberapa karakteristik dari hama ini ialah sebagai berikut : a) Imago ketika masih umur muda berwarna coklat agak kemerahan, setelah tua warnanya berubah menjadi hitam. Kedua buah sayap bagian depan masing-masing terdapat dua buah bercak berwarna kuning agak kemerahan; b) Panjang tubuh imago antara 3,5 - 5 $\mathrm{mm}$, tergantung dari tempat hidup larvanya, artinya pada material yang lebih besar (misalnya butiran jagung atau potongan gaplek) ukuran tubuhnya lebih besar yaitu sekitar $4,5 \mathrm{~mm}$ daripada larva yang hidup pada butiran beras; c) Larvanya tidak berkaki, berwarna putih jernih. Ketika melakukan gerakan tubuhnya selalu membentuk seperti agak bulat mengkerut, sedangkan kepompongnya tampak seakan-akan telah dewasa (Anonim, 2010; Manueke, 1993; Syarief dan Halid, 1993)

Serangga ini mengalami metamorfosa sempurna (holometabola) yaitu dalam perkembangan dari telur sampai dewasa melalui empat stadium yaitu telur, larva, pupa dan imago. Imago merusak butiran bahan dengan bentuk alat mulutnya yang khas yaitu berbentuk seperti moncong (rostrum), dikhususkan untuk melubangi butiran beras, butiran jagung atau bebijian lainnya yang keras. Bebijian yang terserang, terutama beras akan menjadi berlubang-lubang kecil-kecil sehingga mempercepat hancurnya bijian tersebut menjadi seperti tepung. Kerusakan yang berat mengakibatkan adanya gumpalan-gumpalan pada bahan pascapanen akibat adaanya/bercampurnya air liur larva dan kotoran yang dihasilkan oleh serangga (Mallis, 2004; Kartasapoetra, 1991; Surtikianti, 2004; Hilton and Corbet, 1975; Hill, 1990).

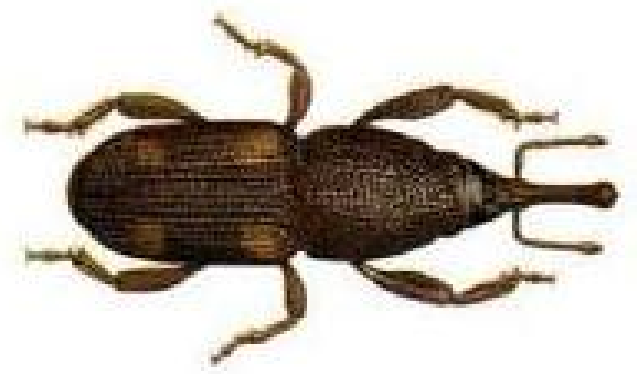

Gambar 1. Imago Sitophilus spp. (Sumber : Anonim, 2010)

Figure 1. Imago of Sitophilus sp. (Source : Animous, 2010) 
Hama S. zeamais memiliki inang utama Jagung pipilan/biji Jagung, dan memiliki tubuh sedikit lebih besar dari $S$. oryzae. Serangga ini oleh para ahli dikenal sebagai Corn Weevil atau bubuk jagung karena merupakan hama utama pada jagung pipilan. Sedangkan S. oryzae dikenal dengan nama bubuk beras atau rice weevil, karena merupakan hama utama pada beras dan gabah. Imago berbentuk bulat memanjang dengan kepala dan alat mulut memanjang dan meruncing ke depan membentuk moncong atau rostrum (snout). Tipe alat mulut ini disesuaikan/dikhususkan untuk menggerek/melubangi bebijian yang keras seperti beras, jagung pipilan dan lain-lain. Tubuh berwarna hitam, sayap depan (elytra) masing-masing memiliki dua bercak berwarna kuning agak pucat. Bagian pronotum mempunyai lekukan lekukan yang kecil dan bundar (Anonim, 2010; Floyd and Newson, 1959; Suputra, 2003)

Penelitian ini bertujuan untuk mengetahui perbedaan stadia perkembangan, siklus hidup, lama hidup, fekunditas, mortalitas dan rasio kelamin S. oryzae dan S. zeamais pada beras dan jagung pipilan.

\section{METODE PENELITIAN}

Penelitian dilaksanakan di Laboratorium Entomologi dan Hama Tumbuhan Fakultas Pertanian Universitas Sam Ratulangi Manado. Lamanya penelitian 6 (enam) bulan yaitu dari bulan Juni sampai dengan November 2012. Penelitian dilaksanakan dalam beberapa tahap yaitu stadia perkembangan, siklus hidup, lama hidup, fekunditas, mortalitas dan rasio kelamin.

Penelitian menggunakan metode deskriptif dan substitusi. Setiap sampel yang sudah diamati dianggap sudah rusak dan pada pengamatan berikutnya diganti dengan sampel lain yang memiliki kondisi yang sama. Kemampuan bertelur, siklus hidup, tingkat kematian, serta jumlah serangga jantan dan betina dari S. oryzae dan S.zeamais diamati dan dihitung perbedaan antar kedua spesies dengan menggunakan uji statistik (Nazir, 1985; Zainudin, 2002) .

\section{Stadia Perkembangan dan Siklus Hidup}

Penelitian stadia perkembangan dilakukan terhadap masing-masing 10 butir telur, 10 ekor larva, dan 10 ekor pupa. Serangga yang digunakan untuk setiap stadium berumur sama. Pengamatan stadium telur hanya dilakukan terhadap jumlah telur yang menetas, sehingga jumlah telur yang menetas dianggap serbagai ulangan. Penghitungan stadium telur dimulai dari saat imago betina meletakkan telur sampai telur tersebut menetas menjadi larva. Pengamatan stadium larva dilakukan dengan mensubstitusi telur yang tidak menetas pada pengamatan stadium telur dengan larva yang berumur sama yang sudah disiapkan sebagai cadangan/ pengganti, sehingga menjadi 10 ekor larva. Penghitungan stadium larva hanya dilakukan terhadap larva yang berhasil menjadi pupa sehingga jumlah larva yang diamati dianggap sebagai ulangan. Penghitungan dimulai saat telur menetas jadi larva sampai terjadinya pupasi. Pengamatan stadium pupa dilakukan substitusi sama dengan pada pengamatan telur dan larva sehingga menjadi 10 ekor pupa. Penghitungan stadium pupa hanya dilakukan terhadap pupa-pupa yang berhasil menjadi imago, yaitu dihitung saat larva menjadi pupa sampai pupa menjadi imago. Pengamatan masa praoviposisi dihitung saat pupa menjadi imago sampai imago meletakkan telur. Penghitungan lama hidup imago yaitu di mulai saat pupa menjadi imago sampai imago mati. Siklus hidup dihitung mulai saat telur diletakkan sampai imago betina meletakkan telur pertama kali yaitu terdiri dari stadium telur-larvapupa-masa praoviposisi.

\section{Fekunditas}

Penelitian fekunditas menggunakan masing-masing satu pasang $S$. oryzae dan $S$. zeamais yang dipelihara pada beras dan jagung pipilan yang diulang sebanyak lima kali. Sepasang imago $S$. oryzae yang berumur sama (umur 1-2 hari) dipelihara dalam 15 gram beras dalam botol tansparan ukuran diameter $15 \mathrm{~cm}$, tinggi $25 \mathrm{~cm}$. Botol-botol tersebut disungkup dengan kain sifon putih dan ditutup dengan penutupnya. Hal yang sama dilakukan juga terhadap $S$. zeamais pada jagung pipilan. 
Pengamatan fekunditas dilakukan setiap hari dengan menghitung jumlah butir beras dan jagung yang sudah diteluri $S$. oryzae dan $S$. zeamais. Butir-butir beras dan jagung yang sudah diteluri langsung dipisahkan dari botol peliharaan dan dipindahkan pada stoples lain yang sudah disiapkan. Pengamatan dilakukan sampai imago betina berhenti meletakkan telur.

\section{Mortalitas dan Rasio Kelamin}

Pengamatan mortalitas dilakukan terhadap 50 butir telur berumur sama (umur $1-2$ hari) yang diulang sebanyak 4 kali. Telur tidak bisa diamati secara langsung karena diletakkan oleh imago betina di dalam lubang yang dibuat oleh imago jantan dan betina sebelumnya. Pengamatan telur didasarkan pada lubang gerekan imago pada butiran beras maupun jagung yang ditutupi dengan zat gelatine yang dihasilkan oleh imago tersebut. Tanda menetasnya telur menjadi larva dalam biji Jagung ialah terdapatnya lubang kecil pada penutup lubang gerekan yang terbuat dari tepung sisa gerekan yang direkat dengan zat gelatine yang dibuat oleh betina saat meletakkan telur. Mortalitas telur dihitung dari jumlah telur yang tidak menetas (jumlah biji yang tidak berlubang pada lapisan penutup lubang tempat peletakan telur) terhadap jumlah telur secara keseluruhan (jumlah butir beras dan jagung yang diteluri).

Pengamatan rasio kelamin didasarkan pada 50 ekor imago berumur sama (umur 1-2 hari) yang diambil secara acak dari populasi pada stok pemeliharaan, yang diulang sebanyak 5 kali. Penghitungan rasio kelamin dilakukan dengan membandingkan jumlah imago jantan terhadap betina.

\section{Analisis Data}

Data perbedaan stadia perkembangan dan siklus hidup, fekunditas, mortalitas dan rasio kelamin dianalisis dengan sidik ragam menggunakan program aplikasi SPSS 17.0 for windows (Nazir, 1985; Zainudin, 2000). Semua data hasil pengamatan dilakukan uji prasyarat analisis parametri untuk semua parameter yang diukur meliputi : 1) Analisis normalitas data dianalisis dengan uji Kolmogorov-Smirnov, dengan tingkat kemaknaan $a=0,05 ; 2)$ Analisis homogenitas varians data menggunakan analisis Levene test; dan 3) Perbedaan S.oryzae dan S. zeanais untuk setiap parameter pengamatan (perbedaan stadia perkembangan dan siklus hidup, fekunditas, mortalitas dan rasio kelamin) dilakukan dengan analisis oneway anova yang dilanjutkan dengan LSD Post Hoc Test pada taraf $\alpha=0,05$.

\section{HASIL DAN PEMBAHASAN}

\section{Stadia Perkembangan dan Siklus Hidup Stadia Perkembangan}

Serangga Sitophilus sp. termasuk kelompok serangga yang mengalami metamorfosis sempurna (holometabola). Pertumbuhan dan perkembangan serangga ini melalui empat tahap perkembangan (stadia) yaitu stadium telur, stadium larva, stadium pupa, dan imago (Gambar 2).

Pengujian perbedaan stadia perkembangan S. oryzae dan S. zeamais dapat diikuti pada Tabel 1. Hasil pengujian perbedaan stadia perkembangan $S$. oryzae dan $S$. zeamais menunjukkan perbedaan yang sangat nyata mulai dari stadium telur, larva, pupa, dan masa praoviposisi.

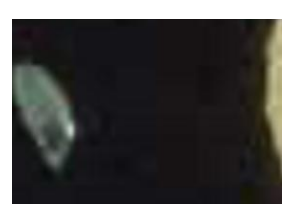

A

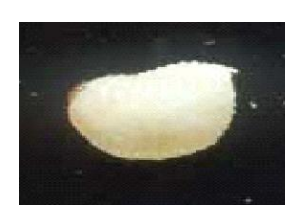

$B$

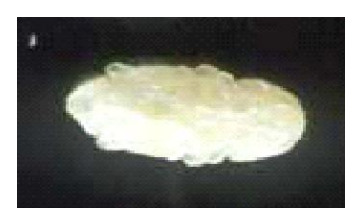

C

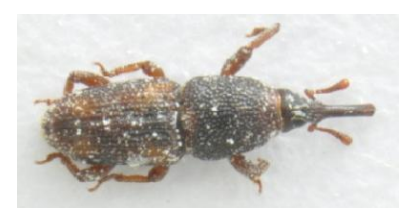

D

Keterangan : $A=$ Telur; $B=$ Larva; $C=$ Pupa; $D=$ Imago.

Gambar 2. Stadia Perkembangan Sitophilus sp. (Pemkbesaran : 15X).

(Figure 2. The Development Stadia of Sitophilus sp. (Magification : 15 times) 
Tabel 1. Hasil Pengujian Perbedaan Stadia Perkembangan Sitophilus oryizae dan Sitophilus zeamais Di laboratorium

(Table 1. Difference Test Results of the Development Stadia of Sitophilus oryzae and S. zeamais at the Laboratory)

\begin{tabular}{cccccc}
\hline No. & Stadia Perkembangan & $\begin{array}{c}\text { Waktu Stadium } \\
\text { (Hari) }\end{array}$ & $\begin{array}{c}\text { Standar } \\
\text { Deviasi } \\
(\mathrm{Sd})\end{array}$ & $\mathrm{t}$ & Sig (t-tailed) \\
\hline 1. & Telur : S. oryzae & 4.0000 & 0,89443 & $3.841^{* *}$ & 0,003 \\
2. & S. zeamais & 5.8333 & 0,75277 & & \\
& Larva : S. oryzae & 17.6667 & 0.81650 & $9.503^{* *}$ & 0,000 \\
3. & S. zeamais & 23.3333 & 1.21106 & & \\
& Pupa : S. oryzae & 8.0000 & 0.89443 & $7.746^{* *}$ & 0,000 \\
4. & S. zeamais & 12.0000 & 0.89443 & & \\
& Masa Praoviposisi : & & & & 0,003 \\
& S. oryzae & 4.8333 & 0.98319 & $3.956^{* *}$ & \\
\hline
\end{tabular}

Keterangan : ** $=$ berbeda sangat nyata

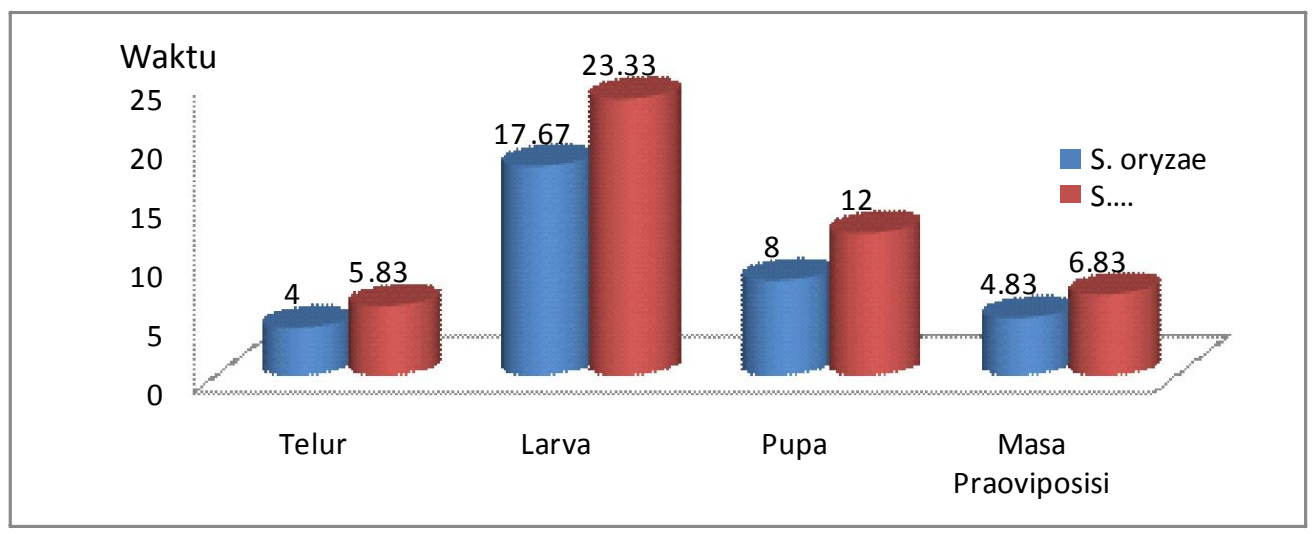

Gambar 3. Diagram Batang Stadia Perkembangan Sitophilus oryzae dan Sitophilus zeamais Pada Beras dan Jagung Pipilan Di Laboratorium

(Figure 3. Bar Chart of Development Stadia of Sitophilus oryzae and S. zeamais on Rice and Seeds Corn at the Laboratory)

Hasil uji t perbedaan stadium telur, larva, pupa, dan masa praoviposisi antara $S$. oryzae dan $S$. zeamais menunjukkan nilai signifikasi 0,003 , $0,000,0,000$, dan $0,003<0,01$. Hal ini mengindifikasikan bahwa setiap stadium perkembangan dari S. oryzae dan S. zeamais memiliki perbedaan yang sangat nyata.

Perbedaan masing-masing stadium perkembangan kedua spesies tersebut dapat dilihat pada Gambar 3.

Diagram batang (Gambar 3) menunjukkan bahwa lama stadium telur $S$. oryzae 4,0 hari, stadium larva 17,67 hari, stadium pupa 8,0 hari dan masa praoviposisi 4,83 hari. Stadium telur $S$. zeamais 5,83 hari, larva 23,33 hari, pupa 12,0 hari dan masa praoviposisi 6,83 hari. Khusus stadium larva mengalami lima instar dan antara pergantian instar satu dengan lainnya ditandai dengan berhentinya aktifitas makan/berdiam diri dan terjadi pergantian kulit/pelepasan kulit yang lama.

\section{Siklus Hidup}

Hasil uji statistik perbedaan siklus hidup $S$. oryzae dan S. zeamais dapat dilihat pada Tabel 2. 
Hasil pengujian perbedaan siklus hidup $S$. oryzae dan $S$. zeamais menunjukkan perbedaan yang sangat nyata.

Hasil uji $t$ perbedaan siklus hidup $S$. oryzae dan $S$. zeamais menunjukkan nilai signifikansi $0,00<0,01$. Hal ini mengindifikasikan bahwa antara siklus hidup $S$. oryzae dan $S$. zeamais menunjukkan perbedaan yang sangat nyata.

Perbedaan siklus hidup S. zeamais dan S. zeamais dapat dilihat pada Gambar 4.

Diagram batang (Gambar 5) menunjukkan bahwa siklus hidup $S$. zeamais lebih panjang dari S. oryzae. Siklus hidup $S$. oryzae 34,5 hari dan $S$. zeamais 48,0 hari. Panjangnya siklus hidup $S$. zeamais dibandingkan dengan $S$. oryzae disebabkan karena tubuh $S$. zeamais lebih besar dari $S$. zeamais.

Hasil pengamatan mengenai rentang hidup organisme yang hidup di muka bumi secara umum memiliki kecendrungan bahwa makin besar tubuh makluk hidup makin panjang rentang hidup- nya, demikian sebaliknya makin kecil besar tubuh, makin pendek rentang hidupnya. Kondisi-kondisi ekstrim tertentu dapat mempengaruhi biologi dan hal ini akan sangat tergantung jenis dan ordo serangganya (Patton, 1963; Bursell, 1970; Boughey, 1973; Mathews and Mathews, 1978; Krebs, 1978; ).

\section{Lama Hidup Imago}

Hasil uji statistik perbedaan lama hidup imago $S$. oryzae dan $S$. zeamais dapat diikuti papa Tabel 3. Hasil pengujian perbedaan lama hidup $S$. oryzae dan $S$. zeamais menunjukkan perbedaan yang sangat nyata.

Hasil uji t perbedaan lama hidup imago $S$. oryzae dan $S$. zeamais menunjukkan nilai signifikansi $0,00<0,01$. Hal ini mengindikasikan bahwa antara siklus hidup $S$. oryzae dan $S$. zeamais menunjukkan perbedaan yang sangat nyata.

Perbedaan lama hidup imago $S$. oryzae dan S. zeamais dapat diikuti pada Gambar 5.

Tabel 2. Hasil Pengujian Perbedaan Siklus Hidup Sitophilus oryzae dan S. zeamais di Laboratorium (Table 2. Difference Test Results of the Life Cycle of Sitophilus oryzae and S. zeamais at the Laboratory)

\begin{tabular}{cccccc}
\hline No. & Jenis Serangga & $\begin{array}{c}\text { Siklus Hidup } \\
\text { (Rata-rata) }\end{array}$ & Sd & $\mathrm{t}$ & Sig (t-tailed) \\
\hline 1. & Sitophilus oryzae & 34,5 & 1,52 & $13,17^{* *}$ & 0,00 \\
2. & Sitophilus zeamais & 48,0 & 2,0 & & \\
\hline
\end{tabular}

Keterangan : ** $=$ Berbeda sangat nyata

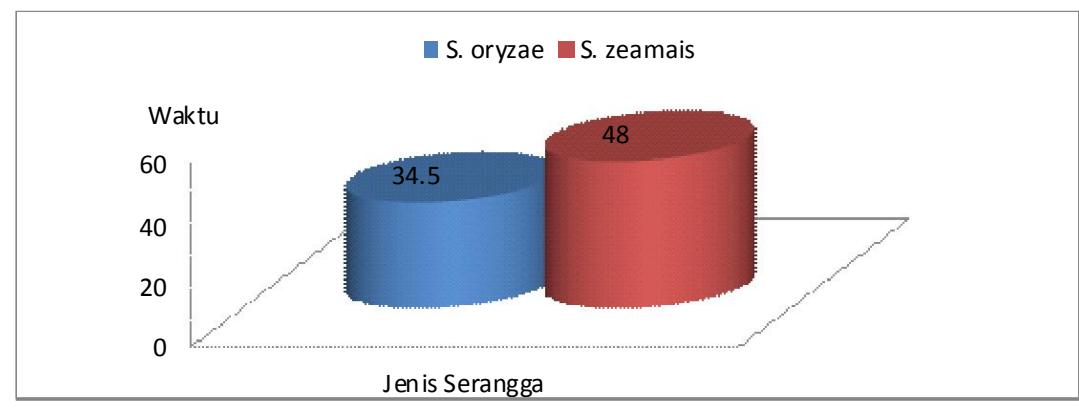

Gambar 4. Diagram Batang Siklus Hidup Sitophilus oryzae dan Sitophilus zeamais Pada Beras dan Jagung Pipilan Di Laboratorium

(Figure 4. Bar Chart of Life Cycle of Sitophilus oryzae and S. zeamais on Rice and Seeds Corn at the Laboratory) 
Tabel 3. Hasil Pengujian Perbedaan Lama Hidup Imago Sitophilus oryzae dan Sitophilus zeamais di Laboratorium

(Table 3. Difference Test Results of the Imago Long Life of Sitophilus oryzae and S. zeamais at the Laboratory)

\begin{tabular}{cllcccc}
\hline No. & Jenis Kelamin & Jenis Serangga & $\begin{array}{c}\text { Siklus Hidup } \\
\text { (hari) }\end{array}$ & $\begin{array}{c}\text { Standar } \\
\text { Deviasi (Sd) }\end{array}$ & t & Sig \\
\hline 1. & Jantan & Sitophilus oryzae & 88.75 & 4.56 & $8,21^{* *}$ & 0,00 \\
& & Sitophilus zeamais & 109.25 & 5.39 & & \\
2. & \multirow{2}{*}{ Betina } & Sitophilus oryzae & 101.75 & 3.69 & $9,81^{* *}$ & 0,00 \\
& & Sitophilus zeamais & 125.75 & 5.85 & & \\
\hline
\end{tabular}

Keterangan : ** = Berbeda sangat nyata.

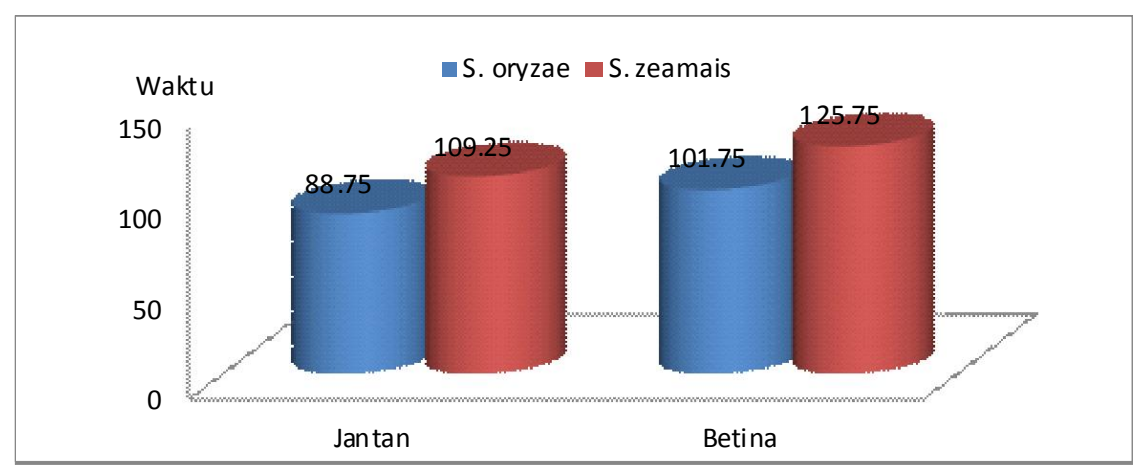

Gambar 5. Diagram Batang Susut Berat pada Beras dan Jagung Pipilan Akibat Serangan Sitophilus oryzae dan Sitophilus zeamais Di Laboratorium.

(Figure 5. Bar Chart of Weight Lossed on Rice and Seeds Corn Caused by Sitophilus oryzae and S. zeamais at the Laboratory)

Gambar 5 menunjukkan bahwa lama hidup imago S. oryzae lebih pendek dari S. zeamais dan lama hidup imago betina lebih panjang dari imago jantan. Lama hidup Imago $S$. oryzae yaitu jantan 88,75 hari dan betina 101,75 hari sedangkan lama hidup imago S. zeamais jantan 109,25 hari dan betina 125,75 hari.

\section{Fekunditas}

Hasil pengujian terhadap data perbedaan fekunditas $S$. oryzae dan $S$. zeamais dapat diikuti pada Tabel 4. Hasil pengujian perbedaan fekunditas $S$. oryzae dan $S$. zeamais menunjukkan perbedaan yang sangat nyata.

Hasil uji t perbedaan lama hidup imago $S$. oryzae dan $S$. zeamais menunjukkan nilai signifikansi $0,00<0,01$. Hal ini mengindifikasikan bahwa antara fekunditas $S$. oryzae dan S. zeamais menunjukkan perbedaan yang sangat nyata. Perbedaan lama hidup imago $S$. oryzae dan $S$. zeamais dapat diikuti pada Gambar 6.

Diagram batang (Gambar 6) menunjukkan bahwa kemampuan bertelur $S$. zeamais lebih tinggi dari S. oryzae. Kemampuan bertelur seekor betina S. oryzae rata-rata 197,2 butir, terdiri dari periode peneluran pertama 25,6 butir, periode kedua 47,6 butir, periode kitiga 46,8 butir, periode keempat 41,8 butir dan periode kelima 35,4 butir. Kemampuan bertelur $S$. zeamais rata-rata 259,2 butir, terdiri dari periode peneluran pertama 51,2 butir, periode kedua 58,4 butir, periode ketiga 52,8 butir, periode keempat 65,0 butir, dan periode kelima 31,8 butir. 
Tabel 4. Hasil Pengujian Perbedaan Fekunditas Sitophilus oryzae dan Sitophilus zeamais Di Laboratorium

(Table 4. DifferenceTtest Results of the Fecundity of Sitophilus oryzae and S. zeamais at the Laboratory)

\begin{tabular}{clcccc}
\hline No. & Jenis Serangga & Fekunditas (butir) & Sd & t & Sig (1-tailed) \\
\hline 1. & Sitophilus oryzae & 197.80 & 13.027 & & \\
2. & Sitophilus zeamais & 259.20 & 16.664 & $6,49^{* *}$ & 0,00 \\
\hline
\end{tabular}

Keterangan : ** = Berbeda sangat nyata

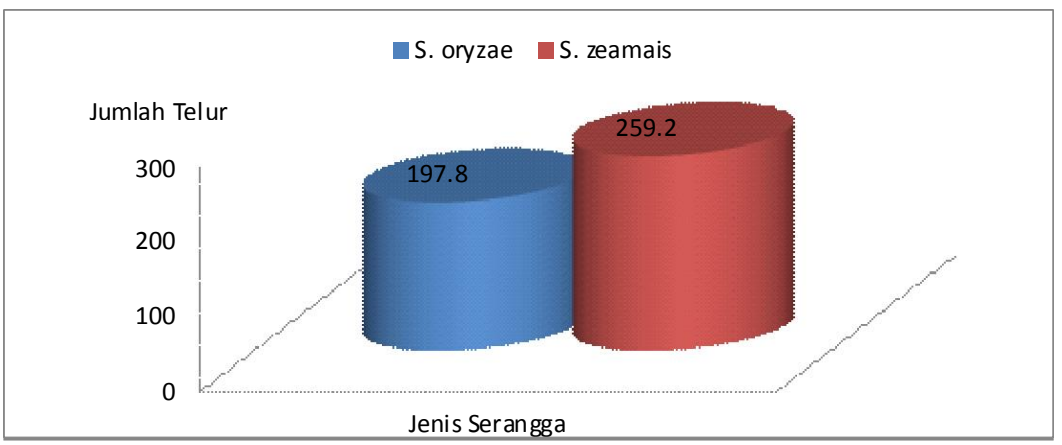

Gambar 6. Diagram Batang Fekunditas Sitophilus oryzae dan Sitophilus zeamais pada Beras dan Jagung Pipilan Di Laboratorium.

(Figure 6. Bar Chart of Fecundity of Sitophilus oryzae and S. zeamais on Rice and Seeds Corn at the Laboratory)

Tabel 5. Hasil Pengujian Perbedaan Mortalitas Pradewasa Sitophilus oryzae dan Sitophilus zeamais Di Laboratorium

(Table 5. Difference Test Results of the Immature Mortality of Sitophilus oryzae and S. zeamais at the Laboratory)

\begin{tabular}{lccccc}
\hline No. & Stadia Perkembangan & $\begin{array}{c}\text { Mortalitas } \\
(\%)\end{array}$ & $\begin{array}{c}\text { Standar Deviasi } \\
(\mathrm{Sd})\end{array}$ & $\mathrm{t}$ & Sig (t-tailed) \\
\hline 1. & Telur : S. oryzae & 38.5000 & 3.41565 & $0.701^{\text {tn }}$ & 0.512 \\
& S. zeamais & 37.0000 & 2.58199 & & \\
2. & Larva : S. oryzae & 32.5000 & 4.43471 & $0.715^{\text {th }}$ & 0.502 \\
& S. zeamais & 30.5000 & 3.41565 & & \\
3. & Pupa : S. oryzae & 9.0000 & 2.58199 & $0.311^{\text {tn }}$ & 0.766 \\
& S. zeamais & 9.5000 & 1.91485 & & \\
\hline
\end{tabular}

Keterangan : $\mathrm{tn}=$ Tidak nyata.

Hill (1990) menyatakan bahwa S. oryzae dan S. zeamais memiliki daya reproduksi yang tinggi pada biji-bijian yang mengandung karbohidrat yang tinggi. Hasil penelitian Manueke (1993) menjelaskan bahwa $S$. oryzae yang dipelihara pada Beras IR-36, Cisadane, dan IR-64 dengan masing 6 ekor imago dengan perbandingan jantan dan betina 2 : 4 menunjukkan bahwa pada minggu ke-14 setelah infestasi populasinya menjadi 3767,33 ekor pada IR-36, 3620,66 ekor pada Cisadane, dan 3538,33 ekor pada IR-64.

\section{Mortalitas}

Hasil pengujian terhadap data mortalitas S. oryzae dan S. zeamais dapat diikuti pada Tabel 5. Hasil pengujian data mortalitas $S$. oryzae dan $S$. zeamais tidak menunjukkan perbedaan yang nyata. Hasil uji t perbedaan mortalitas telur, larva, dan pupa $S$. oryzae dan $S$. zeamais menunjukkan nilai signifikansi $0,0512,0,502,0,766>0,05$. Hal ini mengindifikasikan bahwa mortalitas telur, larva, dan pupa $S$. oryzae dan $S$. zeamais menunjukkan perbedaan yang tidak nyata. 
Tabel 6. Hasil Pengujian Perbedaan Rasio Kelamin Sitophilus oryzae dan S. zeamais Di Laboratorium (Table 6 Difference Test Results of the Sex Ratio of Sitophilus oryzae and S. zeamais at the Laboratory)

\begin{tabular}{|c|l|c|c|c|c|}
\hline No. & \multicolumn{1}{|c|}{ Jenis Serangga } & Rasio Kelamin & $\begin{array}{c}\text { Standar Deviasi } \\
(\mathrm{Sd})\end{array}$ & $\mathrm{t}$ & $\begin{array}{c}\text { Sig } \\
(1-\text { tailed })\end{array}$ \\
\hline 1 & Sitophilus oryzae & 0,79 & 0,098 & & \\
2 & Sitophilus zeamais & 0,78 & 0,079 & $0,39^{\text {tn }}$ & 0,35 \\
\hline
\end{tabular}

Keterangan : $\mathrm{tn}=$ Tidak nyata

Mortalitas S. oryzae dan S. zeamais di laboratorium tinggi yaitu S. oryzae $80 \%$ terdiri dari mortalitas telur $38,5 \%$, larva $32,5 \%$, dan pupa $9,0 \%$, dan S. zeamais $77,0 \%$ terdiri dari mortalitas telur $37,0 \%$, larva $30,5 \%$, dan pupa $9,5 \%$. Mortalitas tertinggi terjadi pada stadium telur, kemudian diikuti oleh stadium larva, dan stadium pupa. Mortalitas merupakan salah satu faktor penting dalam pertumbuhan dan perkembangan serangga. Tingginya mortalitas tersebut merupakan faktor pembatas utama dalam mengontrol perkembangan populasi S. oryzae dan S. zeamais yang sangat tinggi di alam. Penyebab tingginya mortalitas telur pada perkembangan sitophilus adalah stadium telur sangat pekah terhadap gangguan faktor lingkungan, terutana lingkungan fisis seperti suhu dan kelembaban. Khusus untuk stadium larva, faktor yang dominan adalah makanan dan mkusuh alami.

\section{Rasio Kelamin}

Hasil uji statistik perbedaan rasio kelamin S. zeamais dan S. oryzae dapat diikuti pada Tabel 6 . Hasil pengujian data rasio kelamin $S$. oryzae dan $S$. zeamais tidak menunjukkan perbedaan yang nyata.

Data pada Tabel 6 menunjukkan bahwa rasio kelamin $S$. oryzae dan $S$. zeamais secara statistik tidak berbeda nyata dengan nilai signifikansi 0,79 dan $0,78>0,05$. Hal ini menunjukkan bahwa potensi biotik atau kemampuan berkembang-biak kedua spesies ini sama. Namun ditinjau dari segi pertumbuhan populasi maka kedua spesies ini memiliki potensi berkembang biak yang cukup tinggi. Rasio kelamin yang ideal untuk setiap mahluk adalah $1 \leq 1$ artinya makin kecil rasio kelamin makin banyak individu betina sehingga jumlah individu yang melahirkan atau menghasilkan keturunan besar, dengan demikian maka potensi berkembang-biak S. oryzae dan S. seamais cukup tinggi.

Menurut Tarumingkeng (1992) dan Price (1976), terdapat beberapa faktor pembatas dalam pertumbuhan dan perkembangan serangga yang memiliki pengaruh langsung pada populasi serangga. Faktor-faktor pembatas terdiri dari dua kelompok yaitu density dependent factor dan density independent factor atau ada yang mengelompokkannya menjadi external factor dan internal factor. Fekunditas, mortalitas dan rasio kelamin termasuk dalam kelompok internal factor.

\section{KESIMPULAN}

Berdasarkan hasil penelitian dan pembahasan dapat disimpulkan beberapa hal sebagai berikut : 1) Stadium telur $S$. oryzae 4,0 hari, stadium larva 17,67 hari, stadium pupa 8,0 hari dan masa praoviposisi 4,83 hari. Stadium telur $S$. zeamais 5,83 hari, larva 23,33 hari, pupa 12,0 hari dan masa praoviposisi 6,83 hari; 2) Siklus hidup $S$. oryzae lebih pendek dari $S$. zeamais yaitu 34,5 hari dan 48,0 hari; 3) Lama hidup Imago $S$. oryzae yaitu jantan 88,75 hari dan betina 101,75 hari sedangkan lama hidup imago $S$. zeamais jantan 109,25 hari dan betina 125,75 hari; 4) Fekunditas $S$. oryzae rata-rata 197,2 butir dan S. zeamais rata-rata 259,2 butir; 5) Mortalitas pradewasa dan rasio kdelamin $S$. zeamais dan $S$. oryzae relatif sama, yaitu mortalitas S. oryzae $80,5 \%$ dan S. zeamais $77,0 \%$, rasio kelamin $S$. oryzae 0,79 dan $S$. zeamais 0,78 .

\section{DAFTAR PUSTAKA}

Anonim. 1982. Risalah Lokakarya Pascapanen Tanaman Pangan. Departemen Pertanian Badan Penelitian dan Pengenbangan 
Pertanian Pusat Penelitian dan Pengembangan Tanaman Pangan. Bogor.

2009. Ekologi Hama Pasca Panen. http:/abank-udha123.tripod.com/ekologi hamapascapanen.htm. Diakses 17 Desember 2009.

2010. Sitophilus. From Wikipedia, the free Encyclopedia. http:en.wikipedia.org/wiki/ Sitophilus. Diakses 01 Januari 2010.

Boughey, A.S. 1973. Ecology of Population. Second Edition. The Macmillan Company, New York United Stated of America.

Bursell, E. 1970. An Introduction to Insect Physiology. Academic Press Inc. (London) LTD. London and New York.

Cotton, R.T. 1980. Tamarin Pod-Borer, Sitophilus linearis (Herbst.). Journal of Agricultural Research. Washington D.C. Vol. XX. No. 6. $\quad$ http://preserve.nal.usda.gov/jag/v20/ v20i6/ 200439/a200439.htm. Diakses 21 Maret 2010.

Floyd, E.H. and L.D. Newsom. 1959. Biological study of the rice weevil complex. Annals of the Entomological Society of America, 52:687-695.

Hill, D.S. 1990. Pests of Stored Products and Their Control. CRC Press, Inc. Publishers. Boca Raton. Ann Arbor. Boston.

Hinton, H.E. and A.S. Corbet. 1975. Common Insect Pests Of Stored Food Product. A Guide to Their Identification. 5 th Edition. British Museum (Natural History) Economic Series No. 15. Trustees of the British Museum (Natural History). London.

Kalshoven, L.G.E. 1981. Pests of Crops in Indonesia. PT. Ichtiar Baru-Van Hoeve, Jakarta.
Kartasapoetra, A.G. 1991. Hama Hasil Tanaman Dalam Gudang. Penerbit Rineka Cipta. Cetakan Kedua. Jakarta.

Krebs, C.J. 1978. Ecology : The Experimental Analysis of Distribution and Abundance. Second Edition. Harper and Raw Publisher. New York.

Manueke, J. 1993. Kajian Pertumbuhan Populasi Sitophilus oryzae dan Tribolium castaneum dan Kerusakan yang Ditimbulkan pada Tiga Varietas Beras. Tesis. Program Pascasarjana Universitas Gadjah Mada. Yogyakarta.

Matthews, R.W., and J.R. Matthews, 1978. Insect Behavior. A Wiley-Interscience Publication. John Wley \& Sons, New York. Chichester . Brisbane . Toronto.

Mallis, A. 2004. Handbook of Pest Control. The Behavior, Life History and Control of Household Pests. Ninth Edition. Janie Johns, Wild Rice Press, Inc. GIE Media, Inc.

Nazir, M. 1985. Metode Peneltian. Penerbit : Chalia Indonesia. Jakarta.

Patton, R.L. 1963. Introductory Insect Physiology. W.B. Saunders Compaqny, Philadelphia and London, Toppan Company Limited, Tokyo, Japan.

Price, P.W. 1976. Insect Ecology. John Wiley and Sons. New York.

Suputra. 2003. Catatan Taksonomi dan Sistem Penamaan Sitophilus oryzae dan $S$. zeamais. Jurusan Hama dan Penyakit Tumbuhan. Fakultas Pertanian, Universitas Gadjah Mada. Yogyakarta. http://abank-udha123.tripod.com/klasifikasi hama_pasca_panen.htm. Diakses 22 Januari 2010. 
Surtikanti. 2004. Kumbang Bubuk Sitophilus zeamais Motsch. (Coleoptera: Curculuionidae) dan Strategi Pengendaliannya. Balai Penelitian Tanaman Serealia, Maros 90514. Jurnal Litbang Pertanian, 23/4/2004.

Syarief, R. dan H. Halid, 1993. Teoknologi Penyimpanan Pangan. Kerjasama dengan Pusat Antar Universitas Pangan dan Gizi IPB. Penerbit Arcan. Jakarta.
Tarumingkeng, R.C. 1992. Dinamika Pertumbuhan Populasi Serangga. Pusat Antar Universitas-IImu Hayat Institut Pertanian Bogor.

Tjoa Tjien Mo. 1953. Memberantas Hama-Hama Padi di Sawah dan di Dalam Gudang. Noordhoff, Jakarta.

Zainudin, M. 2000. Metodologi Penelitian. Penerbit: Chalia Indonesia. Jakarta. 